\title{
Electrical energy infrastructure in Poland and its sensitivity to failures as part of the energy security system
}

ABSTRACT: Polish energy security is currently one of the key elements affecting the national security system. Maintaining operational efficiency and the permanent modernization of both, power plants, as well as transformer stations and transmission networks is a starting point of ensuring energy security in our country. This is a significant challenge, taking into account the age of the energy critical infrastructure elements in Poland, as well as the permanent increase of the demand for electricity. This implies a systematic growth of the importance of the issue the country's energy security. The numerous events and anomalies that accompany our everyday life, such as the storms that passed over Poland on the night of August 11-12, 2017, indicate the considerable sensitivity of the critical energy infrastructure on the impact of various negative factors. The security of Polish critical infrastructure connected with the distribution of electricity is particularly at risk. Therefore, it is desirable not only for current repairs and the modernization of the power system elements, but also for the work related to adapting the infrastructure to current and even forecasted needs, challenges and threats. In the face of the presented research results, the reconstruction of the Polish power system, as well as the implementation of innovative solutions in the production, transmission and distribution of energy seems to be unavoidable. Therefore interdisciplinary research and analyses are recommended, allowing the level security of the critical

\footnotetext{
1 Social Science and Security Institute, Siedlce University, ORCID: 0000-0001-9288-9182; e-mail: szmitek@op.pl

2 Institute of Mathematics and Physics, Siedlce University, ORCID: 0000-0002-1291-5908; e-mail: gila@uph.edu.pl

3 Social Science and Security Institute, Siedlce University; e-mail: sylwia.zakrzewska01@gmail.com
} 
infrastructure to be increased through the best possible diagnosis of factors that may even slightly threaten this security.

KEYWORDS: energy in Poland, energy infrastructure, failures of the energy system, energy security

\section{Introduction}

Historically, the development of transmission networks in European countries was determined and stimulated primarily by the needs of the individual countries. Domestic power systems were created independently of the systems built by neighboring countries, meeting local requirements resulting from the country's characteristics, density and population structure, location of the industry regions, access to fuels and other infrastructure. As a consequence, many autonomous systems have been created, working completely separately for individual areas, differing in structure and technical characteristics of transmission networks. Over time, additional differences occurred in the adopted legal and tax solutions. With the emergence and development of community aspirations in Europe, the need to create a common and unified European energy market came into play (Pan-European electricity market) (Report... 2016).

The aim of this work is to analyze the possible vulnerability of the Polish power infrastructure to disturbances caused by sudden phenomena occurring in the geosphere. The picture that emerges from the research shows that many efforts have been taken to ensure energy security in Poland, but also illustrates the scale of how much work and costs Poland still has to bear. In particular, the analysis of the age structure of individual elements of energy infrastructure induces a direction of necessary changes.

\section{Production and consumption of electricity in Poland}

The electricity sector is an industry that groups electricity generating entities, transmission and distribution network operators and entities selling electricity. Full social access and uninterrupted use of the functionality of electricity requires the efficient operation of the extensive system of devices used for its production, transmission and distribution. Currently, three main types of installations generating electricity can be distinguished:

$\downarrow$ professional power plants,

$\downarrow$ combined heat and power plants,

$\checkmark$ industrial heat and power plants (National... 2013).

60 
According to data published by Polskie Sieci Elektroenergetyczne, the total installed and attainable capacity of the power plants in 2016 amounted to 41,396 MW, of which, as shown in Fig. 1, 5.5\% or 2,296 MW were produced in hydroelectric power plants, 28,487 MW (68.8\%) in thermal power plants, where brown coal or hard coal is the fuel, 1,610 MW in thermal power plants with gas (3.9\%), 6,344 MW were created in power plants using wind power and other renewable energy sources $(15.3 \%)$ and $2,659 \mathrm{MW}$ produced in industrial power plants $(6.4 \%)$. It is an increase of $951 \mathrm{MW}$ of generated energy in comparison to 2015 and by 3,815 MW in relation to 2014 (PSE 2018: www.pse.pl).

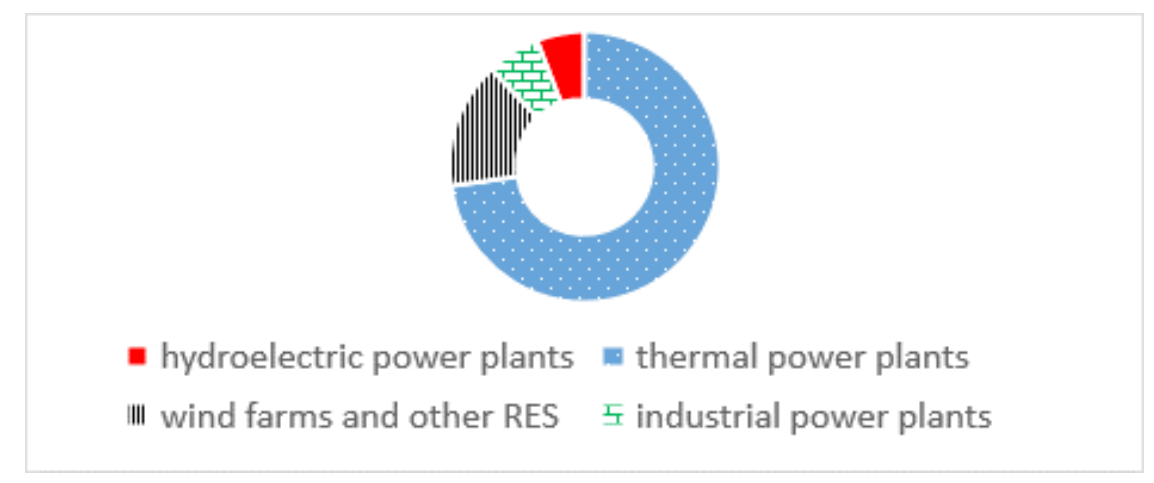

Fig. 1. Percentage of particle elements in the structure of installed capacity in the National Power System

Rys. 1. Udział procentowy poszczególnych elementów wytwórczych w strukturze mocy zainstalowanej w Krajowym Systemie Elektroenergetycznym

The structure of fuel consumption in domestic electricity production has remained unchanged for years and it is dominated by the use of coal. Professional power plants producing energy from hard coal combustion generate $50.2 \%$ of the total domestic electricity production, and the contribution of lignite is determined at $31.5 \%$, i.e. a total of $81.7 \%$ of energy obtained from coal combustion. However, the production of energy from coal combustion is associated with a significant emission of carbon dioxide and sulfur, nitrogen oxides and dust into the atmosphere. The efforts to reduce their emissions, undertaken for several years, resulting from international commitments have contributed to their significant reduction. By 2009, $\mathrm{CO}_{2}$ emissions were reduced by 186 million tons of eq. compared to 1988 , i.e. by $33 \%$, while noting significant economic growth, which turned out to be unattainable in the Western Europe.

In order to illustrate the structure described above in a broader context, Figure 2 shows the share of fuels used to produce electricity in 2016/17 in all of European Union. The fact that this structure is diametrically opposed is visible. However, it turns out that manufacturing technologies based on lignite and hard coal are still the least expensive (EU... 2016), so Poland should not give up, but introduce more modern, more environmentally friendly ways of using them (Polish... 2016).

The largest entities on the Polish energy market are:

- Polska Grupa Energetyczna (GK PGE 2018: www.gkpge.pl):

$\downarrow$ produces $56.52 \mathrm{TWh}$ of electricity, 


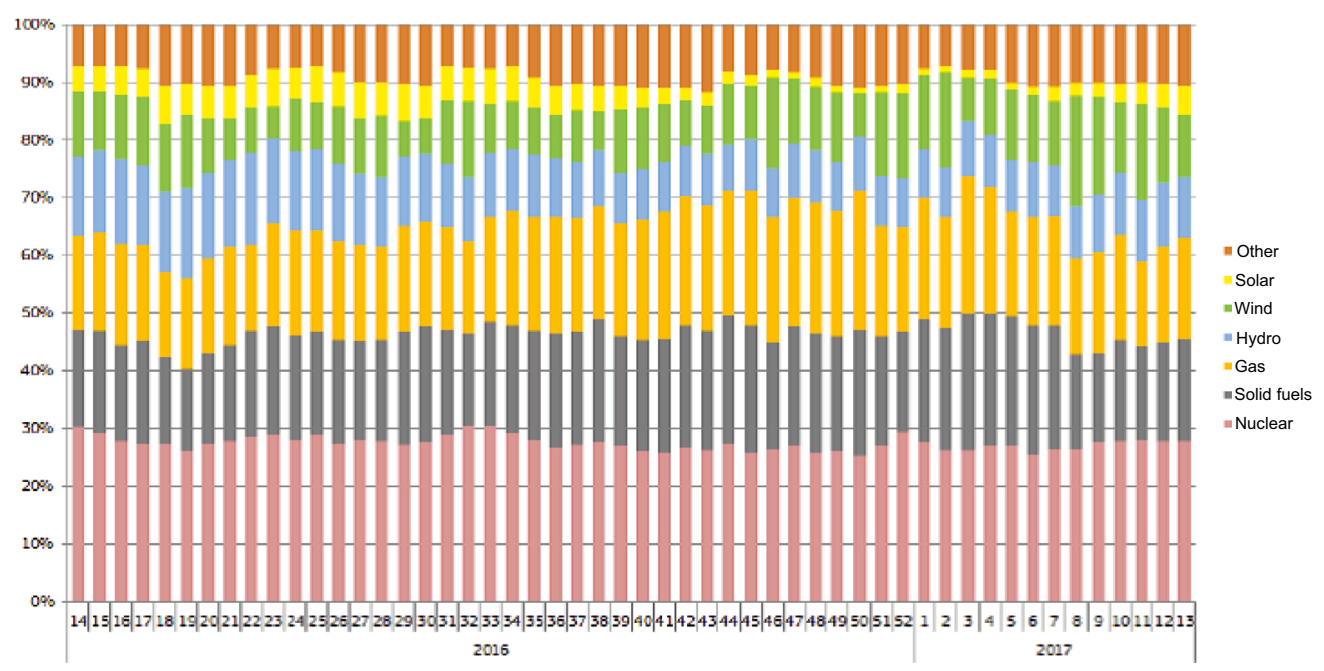

Fig. 2. The average weekly share of individual energy sources used in the production of electricity all of European Union (Quarterly... 2017)

Rys. 2. Średniotygodniowy udział poszczególnych źródeł wykorzystywanych w produkcji elektryczności w skali całej Unii Europejskiej

\ supplies electricity to approx. 5.1 million consumers,

operates 274.7 thousands km of power lines,

t the installed capacity of the PGE Group generation units is $13.1 \mathrm{GW}$,

$\downarrow$ produces 48.9 million tons of brown coal.

$\checkmark$ ENERGA(Energa 2018: www.energa.pl):

^ produces over $4.5 \mathrm{TWh}$ of electricity,

supplies electricity to 2.5 million households and to over 300,000 companies

- operates over 193 thousands $\mathrm{km}$ of power lines,

$\downarrow$ installed capacity of the generation units of the ENERGA Group is equal to approximately 1.2 GW (including approx. 160 MW in the Szczytowo-Pompowa Power Plant operating for Polskie Sieci Elektroenergetyczne SA).

$\downarrow$ TAURON (Tauron 2018: www.tauron-pe.pl):

$\downarrow$ produces 21.4 TWh of electricity,

supplies electricity to over 5.2 million consumers,

\ operates 223.7 thousands km of power lines,

$\downarrow$ installed capacity of generation units of the TAURON Group is $5.6 \mathrm{GW}$,

$\downarrow$ produces 4.58 million tons of commercial coal.

$\checkmark$ ENEA (Enea 2018: www.firma.enea.pl):

$\downarrow$ produces $37 \mathrm{TWh}$ of electricity,

$\downarrow$ provides electricity to 2.4 million customers,

- operates 129 thousands km of power lines,

the installed capacity of the generation units of the Enea Group is $3.2 \mathrm{GW}$.

In addition to the key players: PGE, TAURON, ENEA and ENERGA (Fig. 3), 170 entities selling electricity are currently registered in Poland (Bulletin... 2017). 


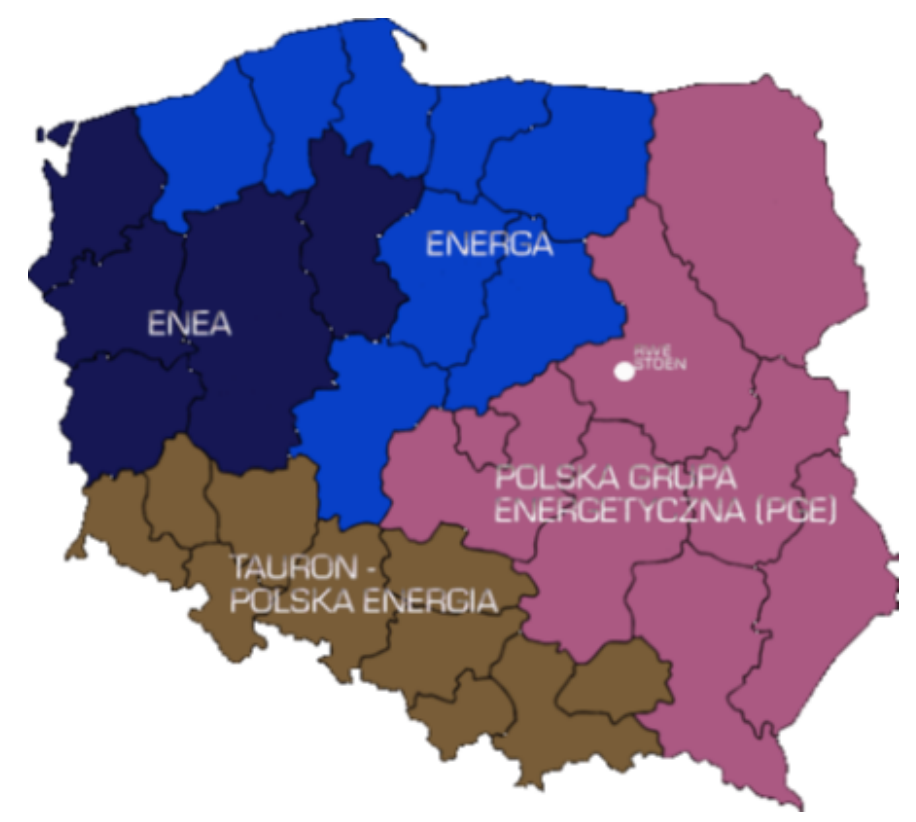

Fig. 3. The reach of the largest entities on the energy market in Poland (National... 2013)

Rys. 3. Zasięg działania największych podmiotów na rynku energii w Polsce

To illustrate the scale of our country's needs, it is worth mentioning that the lowest domestic demand for power in 2017 took place on April 17. The minimum power consumption on that day was 11,785 MW and took place at 5:45 am, while the maximum was 16,489 MW and occurred at $8: 30 \mathrm{pm}$. The amplitude of power consumption on that day was 4,704 MW. However, the highest power consumption was recorded on January 9 . The lowest energy consumption on that day reached the value of 16,998 MW and occurred at 2:15 am, while the largest was 26,231 MW and took place at $5: 30 \mathrm{pm}$. The daily amplitude of the power consumption was 9,232 MW on that day. On the other hand, the amplitude of minimum and maximum annual energy consumption reached the value of 14,445 MW. The domestic demand is constantly growing. On February 28, 2018, a record-breaking demand for electrical power was noted. The registered national demand at 6:30 pm was 26,448 MW (PSE 2018: www.pse.pl).

Compared with 2016, higher energy consumption occurred mainly in the winter and summer months of 2017, i.e. January, February, April, May, August and September. The highest energy consumption in 2016, compared to 2017, ranged from $194 \mathrm{MW}$ in December to 1,088 MW in February. Interestingly, in March 2017 the consumption of energy was lower energy by $25 \mathrm{MW}$ than in the previous year. And the largest annual energy consumption in both 2016 and 2017 occurred in January (24,705 MW in 2016 and 25,325 MW in 2017), February (23,493 MW in 2016 and 24,581 MW in 2017), March (23,264 MW in 2016 and 23,239MW in 2017), October (23,240 MW in 2016 and 23,636 MW in 2017), November (24,578 MW in 2016 and 24,942 MW in 2017) and December (24,739 MW in 2016 and 24,933 MW in 2017) (List... 2017). 
In comparison with 2014 and 2015, in which the electricity production reached $156,567 \mathrm{GWh}$ and $161,772 \mathrm{GWh}$, in 2016 there was another increase in its production, reaching $162,626 \mathrm{GWh}$. The increase of $3.32 \%$ of total energy production from 2014 and $0.53 \%$ of energy was generated in 2015. In the case of energy production in professional power plants, an increase of $1.15 \%$ was recorded in 2015 compared to the previous year, while their share in energy production decreased in 2016 by $0.83 \%$ compared to 2015 . However, the intensification of energy production by wind farms and other renewable energy sources and industrial power plants is taking place, the growth rate was much higher in 2015 being $39.37 \%$ for wind farms and other renewable sources and $8.17 \%$ for industrial power plants, while in 2016 it decreased significantly, reaching $16.37 \%$ and $3.82 \%$, respectively. It is worth mentioning here that on December 20 , 2016, due to the northern storm, Barbara, causing spots (in northern Poland) gusts of wind, reaching a speed of $120 \mathrm{~km} / \mathrm{h}$, the national power grids worked at the highest energy level from wind energy, with the lowest share of conventional power plants. Wind turbines generated up to $34 \%$ of electricity at that time, which is a record level in the history of our country's energy sector (Report... 2017).

It should be emphasized that hydroelectric power plants are losing importance for thermal power plants and wind farms operating since 2006, as well as other renewable energy sources and gas-fired power plants existing since 2005. In 1990, hydroelectric plants generated 3,300 GWh of energy, whereas in 2017 only $2,767 \mathrm{GWh}$. Energy production in thermal power plants increased from 124,899 GWh in 1990 to $139,023 \mathrm{GWh}$ in 2016, and the wind farms and other renewable energy sources allowed to generate $69 \mathrm{GWh}$ of energy in 2006, and 11 years later reached 14,005 GWh (an increase of $20200 \%$ ). The contribution of industrial power plants whose production reached 10,057 GWh in 2016, while in 1990 it was $8,137 \mathrm{GWh}$ (List... 2017). The dynamics of the hydro-power plants productions in Poland are presented in Figure 4.

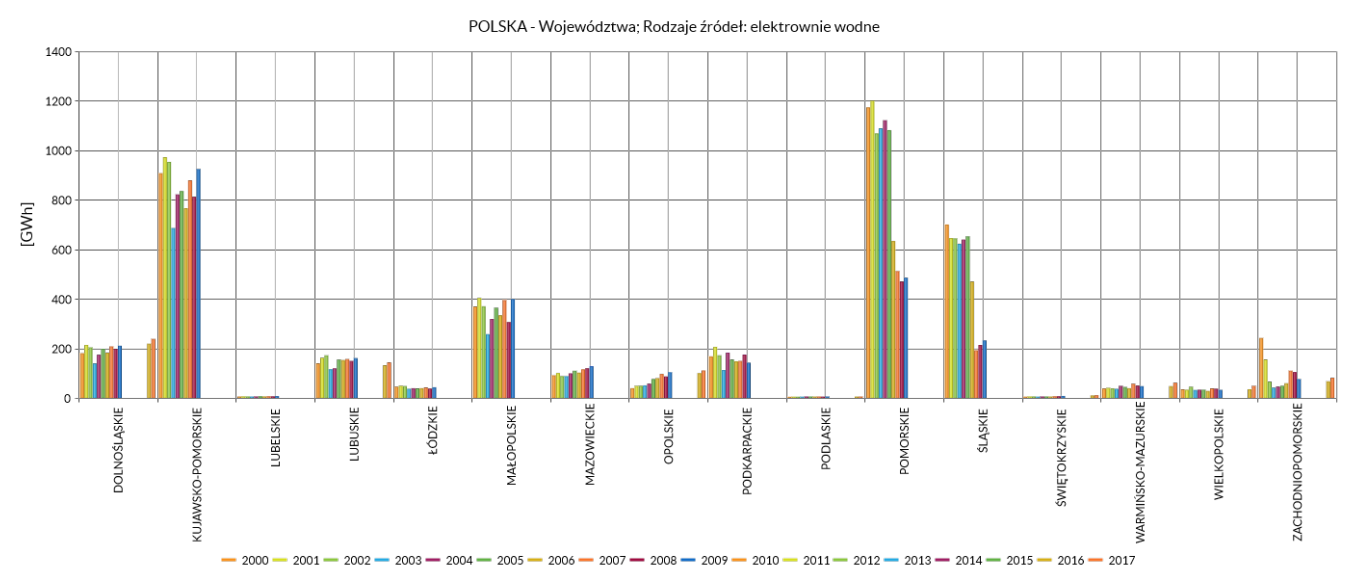

Fig. 4. The dynamics of the hydro-power plants productions in Poland (GUS... 2018)

Rys. 4. Dynamika produkcji energii elektrycznej przez elektrownie wodne w Polsce 
The largest increase in energy production was recorded in the years 1950-1980, from about $10,000 \mathrm{GWh}$ in 1950 to over $120,000 \mathrm{GWh}$ in 1980 . After that time, there were smaller or larger fluctuations in its production and consumption, although the upward trend prevailed. The main fuel for its production until 1962 was hard coal. After this time, the contribution of lignite began to increase, which together, as already mentioned, to the present day, constitutes the main source of produced energy.

In 2017, as mentioned above, domestic electricity production predominated over its consumption only in the two winter months: January and February. In winter months (January, February, March, October, November and December), both the largest production and the consumption of electricity were recorded. The annual balance ended with a higher consumption of electricity than the level of its production. Since 1990, a similar situation occurred only twice, in 2014 (consumption higher than production by 2,166,798 MWh) and in 2016 (consumption higher than production by $2,006,003 \mathrm{MWh}$ ). The largest surpluses in energy production were recorded in 2003-2006. They exceeded 10,000 GWh (List... 2017).

Transmission of energy from the power plant to the recipients is possible thanks to the extensive network of power lines and substations. However, this involves losses. The main method of their reduction consists in increasing the voltage of the power transmission lines. Depending on the distance to which the energy is transmitted, different voltage values are used:

$\checkmark$ from 220 to $400 \mathrm{kV}$ (so-called highest voltages, HV), in the case of long-distance transmission lines;

$\downarrow 110 \mathrm{kV}$ (so-called high voltage, $\mathrm{hV}$ ), in the case of transmission over distances up to several dozen kilometers;

$\downarrow$ from 10 to $30 \mathrm{kV}$ (so-called medium voltage, MV), used in local distribution lines (National... 2013).

Increasing the voltage for transmission purposes, and then lowering it to the level at which it is possible to use the standard electrical devices operating at $220 / 230$ or $380 / 400 \mathrm{~V}$, requires the use of high voltage power system stations, many high voltage distribution stations and numerous transformer stations, changing medium voltage to that commonly used in receiving installations (230 and $400 \mathrm{~V})$.

Currently, technologies that enable energy storage are largely developed, and their commercial implementation is initiated (e.g. in Germany, in 2016, tens of thousands of warehouses operated in low-voltage networks) (Bielecki 2017), however, in Poland there are no possibilities of storing electricity, which means that all the time the amount of energy generated in power plants must be equal to the energy consumed by the customers. Thus, the power system must be able to change the directions and amount of transmitted energy. This is possible thanks to numerous connections between power plants, electricity stations and energy recipient groups. Such connections are provided by a network of power lines that operates at various voltage levels. The more extensive this network is, and the lines with a higher technical and technological level, the greater the chance of reliable energy supply to each recipient. PSE, the owner and host of the highest voltage transmission network in Poland is described above (PSE 2018). The company acts as a distribution system operator (DSO). 
The DSO of electricity is responsible for network traffic within the power transmission system, current and long-term operational security of this system, operation, maintenance, repairs and necessary development of the transmission network, including the construction of connections with other power systems. PSE carries out the tasks of the transmission system operator based on the transmission network of the highest voltage (PSE 2018):

a) 242 lines with a total length of $13,396 \mathrm{~km}$, including:

$\checkmark 1$ line with $750 \mathrm{kV}, 114 \mathrm{~km}$ long,

\ 74 lines with a voltage of $400 \mathrm{kV}$ with a total length of $5,340 \mathrm{~km}$,

$\checkmark 167$ lines with a voltage of $220 \mathrm{kV}$ lines with a total length of 7,942 km;

b) 100 highest voltage (HV) stations;

c) Underground connection $450 \mathrm{kV}$ DC Poland-Sweden with a total length of $254 \mathrm{~km}$.

The obligations of the DSO also include the stability of the system, consisting in balancing the demand for electricity with energy supplies and management of system limitations to ensure the safe operation of the power system.

The main recipients of electricity in Poland are customers buying energy for the needs of their industrial and business activities. Customers buying energy for communal and household purposes make up only $25 \%$ of the total number.

\section{International energy exchange}

The balance of electricity exchange with neighboring countries in recent years is dynamic and takes the form of mutual dependences. Over the years 1990-2016, the exchange of energy with foreign countries usually closed with a negative balance of 333,545 MWh in 2015 to $11,186,089 \mathrm{MWh}$ in 2005. The exceptions were the years 2014 and 2016, where this value was positive. In 2014, it amounted to 2,167 GWh, while in $2016-1,999 \mathrm{GWh}$. The highest energy consumption from abroad was recorded in this period in 2015 and amounted to 14,459,003 MWh, and the lowest in 2000, amounting to 3,289,762 MWh. However, the highest energy donation took place in 2005 and amounted to $16,187,702 \mathrm{MWh}$, and the lowest in 1995 with the value of 7,156,730 MWh. It is shown that international electricity exchange will experience further development (Fig. 5) (Report TOE... 2018).

The reason for this phenomenon is the successive increase in the domestic electricity consumption. In 2015, the energy consumption increased by $1.7 \%$ compared to the previous year, while in 2016 by $1.97 \%$ compared to 2015 , reaching the value of $164,625 \mathrm{GWh}$.

According to the plans of PSE, the following cross-border connections should be expanded (REE 2018: www.rynek-energii-elektrycznej.cire.pl):

a) with Germany:

$\checkmark$ construction of six $400 \mathrm{kV}$ lines;

$\downarrow$ modernization of the $400 \mathrm{kV}$ Krajnik-Morzyczyn-Dunowo line;

66 


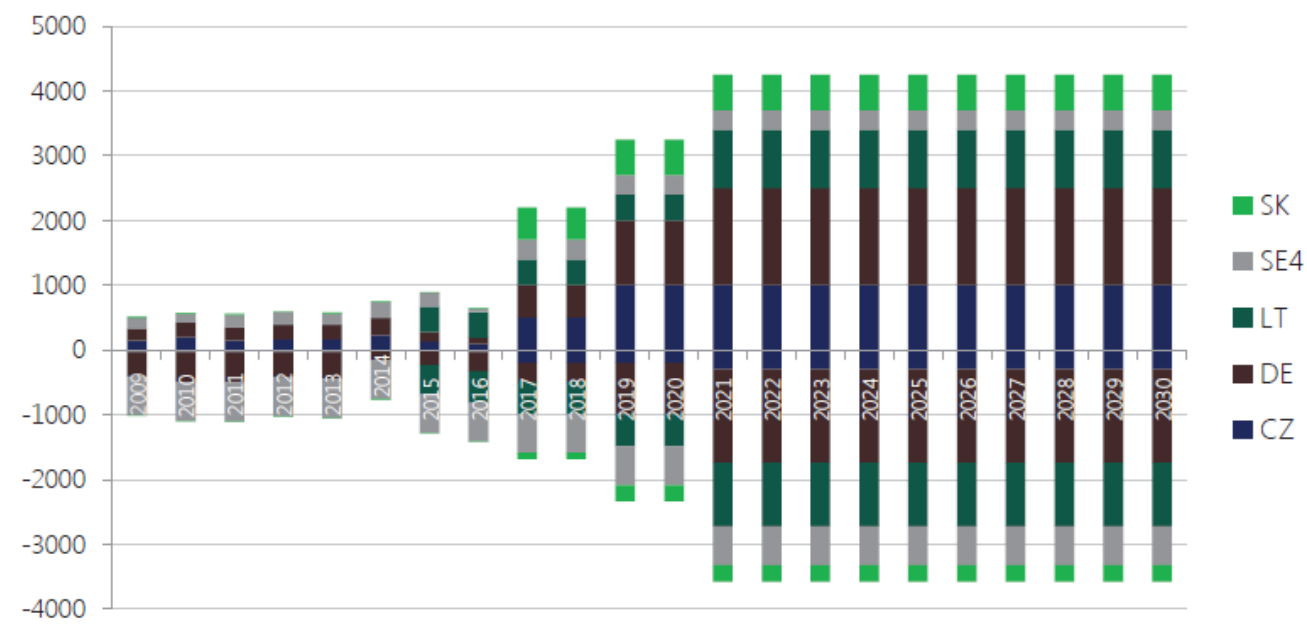

Fig. 5. Maximal international exchange capacity [MW] (PKEE... 2016)

Rys. 5. Maksymalne zdolności wymiany międzynarodowej [MW]

switching of the double-track Krajnik-Vierraden (Germany) line to $400 \mathrm{kV}$;

$\checkmark$ installation of phase shifters in Krajnik station on the $400 \mathrm{kV}$ Krajnik-Vierraden line;

$\checkmark$ construction of a $400 \mathrm{kV}$ switching station at Byczyna.

b) with the Czech Republic and Slovakia:

$\checkmark$ extension of the existing $400 \mathrm{kV}$ Tucznawa-Rzeszów line to Byczyna;

$\downarrow$ modernization of the $400 \mathrm{kV}$ Lagisza-Tucznawa line and both tracks of the $400 \mathrm{kV}$ Tucznawa-Byczyna line;

$\checkmark$ modernization of the $220 \mathrm{kV}$ Moszczenica-Wielopole and Podborze-Moszczenica line;

$\checkmark$ construction of a 2-track inter-system $400 \mathrm{kV}$ Byczyna-Varin line (Slovakia).

c) with Ukraine:

- construction of a 2x600 MVA converter station at Rzeszów;

$\downarrow$ modernization of the $750 \mathrm{kV}$ Rzeszów-Chmielnicka line.

Data from 2016 shows that the balance of the parallel exchange of electricity with foreign countries was $-2,140,741 \mathrm{MWh}$, while the non-parallel exchange rate was 4,146,744 MWh. In total, Poland used 14,016,712 MWh of electricity from abroad, sent 12,011,069 MWh, closing the year 2016 with 2,006,003 MWh of imported energy from abroad. The structure of cross-border connections is shown in Fig. 6 and Table 1. The largest amount of electricity in 2016 was from Germany: 8,753.9 GWh, the lowest from Slovakia: 3.1 GWh. On the other hand, Poland sent the highest amount of energy to the Czech Republic: 7,193.2 GWh, and the lowest to Ukraine: $0 \mathrm{GWh}$. In the international exchange, the negative balance was recorded in the energy exchange with the Czech Republic (-6,688 GWh) and Slovakia $(-4,183.9$ GWh).

The total capacity of the Polish power system connections with the European Union countries is 2,000-3,000 MW (depending on the configuration of the system operation) and is limited by transmission capacity within the national system. 


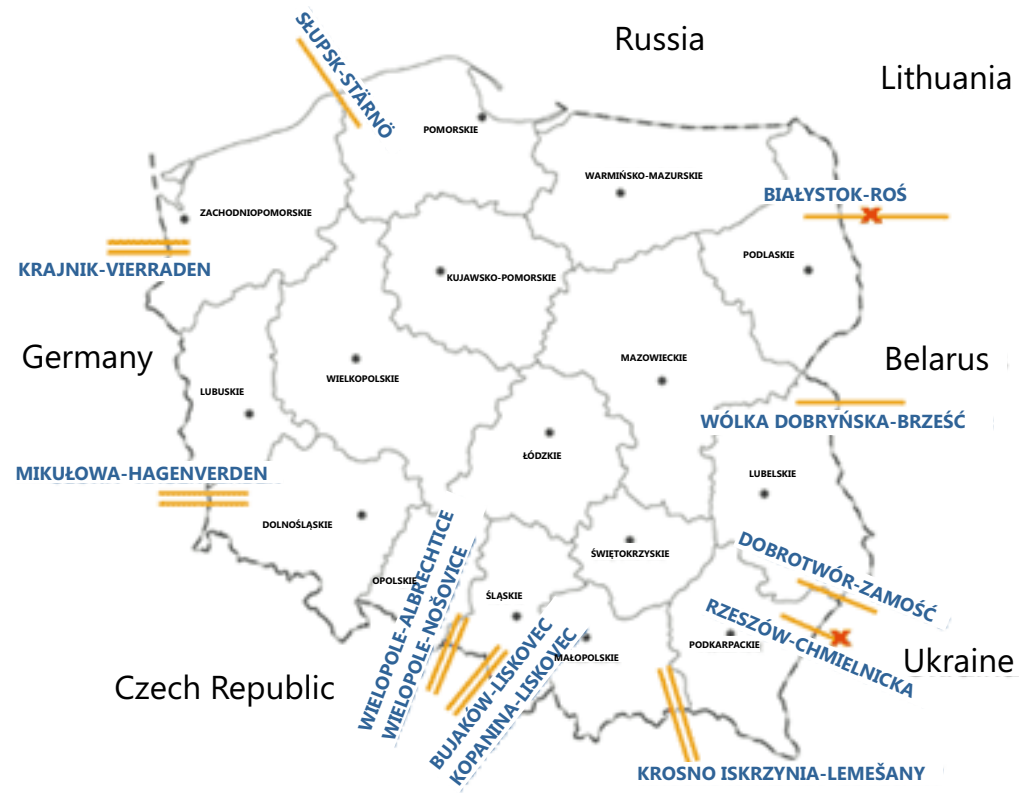

Slovakia

Fig. 6. Cross-border connections (REE 2018)

Rys. 6. Transgraniczne połączenia elektroenergetyczne

TABLE 1. Cross-border connections

TABELA 1. Transgraniczne połączenia elektroenergetyczne

\begin{tabular}{|l|c|c|c|}
\hline \multicolumn{1}{|c|}{ Line } & Voltage $[\mathrm{kV}]$ & Permissible load capacity & $\begin{array}{c}\text { Number } \\
\text { of tracks }\end{array}$ \\
\hline Krajnik-Vierraden & 400 & $778 \mathrm{~A}$ and $296 \mathrm{MW}$ & 2 \\
\hline Mikułowa-Hagenverden & 400 & $2000 \mathrm{~A}$ and $1385 \mathrm{MW}$ & 2 \\
\hline Wielopole-Albrechtice & 400 & $2000 \mathrm{~A}$ and $1385 \mathrm{MW}$ & 1 \\
\hline Wielopole-Nošovice & 400 & $2000 \mathrm{~A}$ and $1385 \mathrm{MW}$ & 1 \\
\hline Bujaków-Liskovec & 220 & $1050 \mathrm{~A}$ and $400 \mathrm{MW}$ & 1 \\
\hline Kopanina-Liskovec & 220 & $1050 \mathrm{~A}$ and $400 \mathrm{MW}$ & 1 \\
\hline Słupsk-Stärno & 450 (direct current) & - & 1 \\
\hline Białystok-Roś & 220 & $608 \mathrm{~A}$ and $231 \mathrm{MW}$ & 1 \\
\hline Wólka Dobryńska-Brześć & 110 & $120 \mathrm{MW}$ & 1 \\
\hline Dobrotwór-Zamość & 220 & $660 \mathrm{~A}$ and $251 \mathrm{MW}$ & 1 \\
\hline Rzeszów-Chmielnicka & 750 & $1500 \mathrm{~A}$ and $1300 \mathrm{MW}$ & 1 \\
\hline Krosno Iskrzynia-Lemešany & 400 & $1200 \mathrm{~A}$ and $831 \mathrm{MW}$ & 2 \\
\hline
\end{tabular}

Source: REE, 2018: www.rynek-energii-elektrycznej.cire.pl. 
The current strength of the cross-border connections meets the objectives recognized by the Council of Europe, which says that at least $10 \%$ of the transmission capacity of cross-border connections in relation to the capacity is installed in the national power system (European Council... 2014).

\section{Determinants of sensitivity to failures of the power infrastructure in Poland and the directions of its modernization}

The Polish energy sector was created almost from scratch in the 1950s and 1960s. During II World War, the greatest destructions occurred in the Warsaw power industry, whose production capabilities practically ceased to exist. However, there were no major damages in the power industry in the Upper Silesia. In the remaining regions, losses varied, ranging from $20 \%$ to $80 \%$. Unfortunately, there was no technical possibility of sending power from the Upper Silesia power plant to Warsaw. There was also no national system, only its beginnings in the form of unrelated local systems (Energetyka Polska 2018: www.energetyka-polska.pl):

$\downarrow 60 \mathrm{kV}$ Upper Silesia line;

$\downarrow 100 \mathrm{kV}$ Lower Silesian line;

४ 110/30 kV Poznań-Gorzów system;

\ $60 \mathrm{kV}$ Gródek-Żur-Gdynia-Pomorze system;

$\checkmark 150 \mathrm{kV}$ line from Rożnów to Tarnów-Starachowice.

At that time the main direction was to meet the needs of heavy industry, which dominated during this period. Current conditions favor the development of the services sector (Holtgrewe 2015), making it the main recipient of the generated electricity. Although during the last twenty years a significant system and technological modernization of the Polish energy sector has been conducted (Dołowy et al. 2015; Bielecki 2017). It still operates on the basis of its original rather archaic solutions (Report... 2015).

The technical conditions of power units in the nearest future require replacements or modernizations due to the high degree of depletion, low efficiency, as well as the previously mentioned, maladjustment to the modern needs and directions of economic development (Report... 2015). This is a costly project, characterized by a significant contribution of long-term fixed costs, and hence risky, due to the lack of certain forecasts regarding future requirements and international regulations (Paska and Surma 2017). An additional problem is the supply of natural gas and crude oil. Large dependence on natural gas imports ( $72 \%$ ), especially from the east ( $80 \%$ of total gas imports) exposes customers to large fluctuations in prices, therefore, at the moment, our country remains helpless (Report... 2012). The attempt to improve this situation is, among others, the opening, in 2015, of the LNG terminal in Świnoujście (named the President Lech Kaczyński Terminal). It made gas imports from the US, among others, possible (The first gas charge on the Clean Ocean gas tank was delivered to the port of Świnoujście on June 7, 2017). However, this 
is only a partial solution in the context of a strategy aimed at increasing the energy security of our country. In addition, the price of gas remains a debatable issue, because a group of experts believe that American fuel is much more expensive than Russian, Qatari or Norwegian fuel. Therefore, it may turn out that its import is not in the economic interest of Poland (Charles... 2018). Nevertheless, it is a good step towards diversifying sources.

The structure of the Polish energy system is determined by a solution that was current more than a half of a century ago. The power plants are located mainly in the vicinity of coal mining areas, i.e. in southern and central Poland (Fig. 7). A significant lack of balance in the deployment of power infrastructure elements has a negative impact on power stability, as well as deficiencies in network development in the northern and eastern regions of our country. Various initiatives such as the international energy connection, LitPol (LitPol 2018) are being undertaken. The age structure of the power plant is quite diverse. Just over $50 \%$ of the power is installed in turbines operating for more than 30 years -183 devices, and nearly $25 \%$ in turbines operating less than 20 years - 111 turbosets (Strategy... 2014). According to the data presented in the BAT (Best Available Techniques) modernization scenario, until 2035, 14,675 MW will be permanently withdrawn from use, with 2,985 MW already as of 2020, from among the existing Centrally Dispatchable Generation Units (Report... 2017).

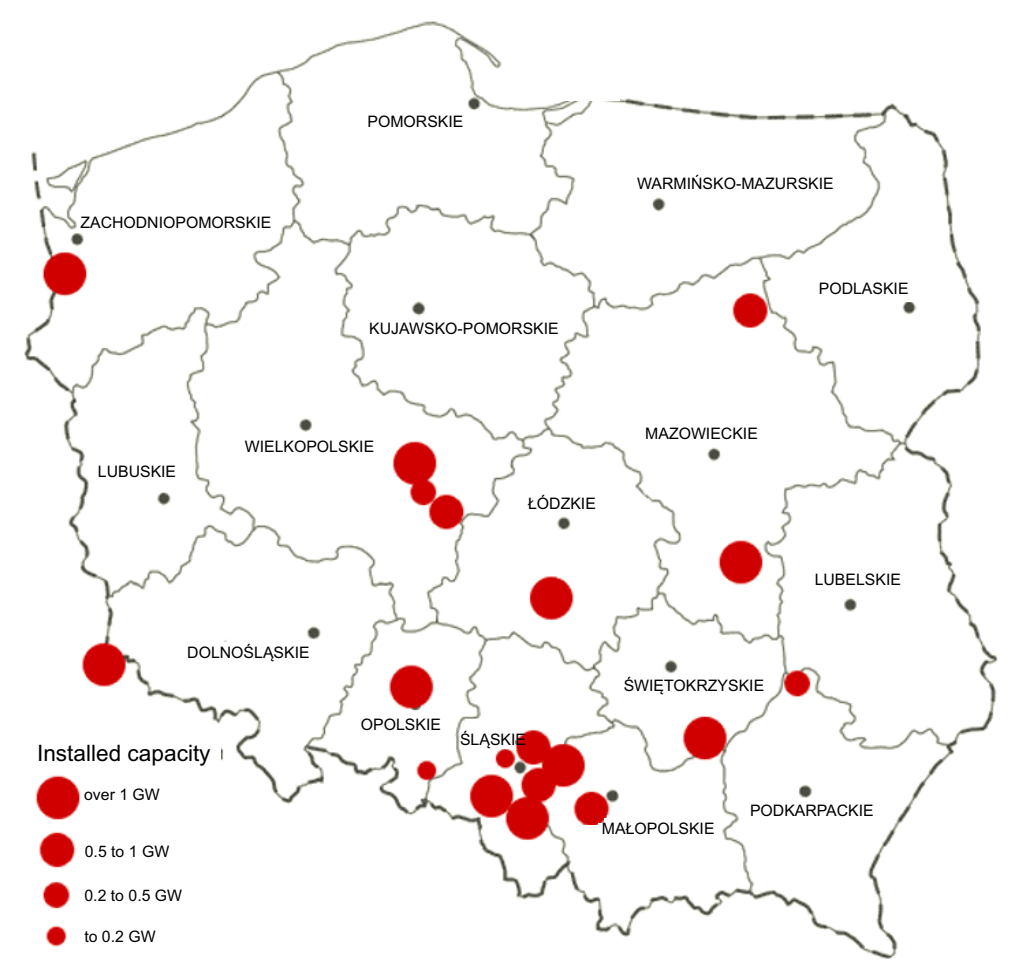

Fig. 7. Location of the largest power plants in Poland (REE 2018: www.rynek-energii-elektrycznej.cire.pl)

Rys. 7. Lokalizacja elektrowni w Polsce 
The advanced age also characterizes a distribution infrastructure. Table 2 highlights the picture of the aging and underinvested network infrastructure. This situation causes a progressive deterioration of the technical condition of the lines and stations. In the case of electricity distribution networks, the highest degree of wear is characteristic for MV and $\mathrm{hV}$ overhead lines. Over $70 \%$ of these lines were built over 25 years ago, and at least $30 \%$ are more than 40 years old.

TABLE. 2. Age structure of selected elements of the electricity distribution network in Poland

TABELA 2. Struktura wiekowa wybranych elementów sieci dystrybucji energii elektrycznej w Polsce

\begin{tabular}{|l|c|c|c|c|}
\hline Elements of electrical network & $\begin{array}{c}\text { Less than 12 years } \\
\text { old }\end{array}$ & $\begin{array}{c}\text { Between 12-27 } \\
\text { years old }\end{array}$ & $\begin{array}{c}\text { Between 27-42 } \\
\text { years old }\end{array}$ & Older than 42 \\
\hline HV Overhead Lines & 0.07 & 0.192 & 0.384 & 0.354 \\
\hline HV Underground PC & 0.634 & 0.366 & 0.000 & 0.000 \\
\hline H/MV Stations & 0.156 & 0.243 & 0.388 & 0.212 \\
\hline HV Transformers & 0.230 & 0.194 & 0.433 & 0.143 \\
\hline MV Underground PC & 0.280 & 0.319 & 0.262 & 0.139 \\
\hline MV Overhead Lines & 0.062 & 0.203 & 0.435 & 0.300 \\
\hline M/LV Stations & 0.147 & 0.251 & 0.368 & 0.234 \\
\hline MV Transformers & 0.271 & 0.276 & 0.355 & 0.099 \\
\hline LV Overhead Lines & 0.317 & 0.334 & 0.251 & 0.098 \\
\hline LV Underground PC & 0.133 & 0.221 & 0.393 & 0.253 \\
\hline
\end{tabular}

Source: Tomczykowski 2015.

Since its inception, due to legislative problems and shortages of appropriate measures, they have not been replaced or modernized in most of the cases. Only the required inspections and repairs were conducted. Also, more than $60 \%$ of the low-voltage cable lines have been functioning for at least 25 years. A similar situation occurs in the case of stations that allow the transition from higher to lower voltage. Over $60 \%$ of both HV/MV stations and MV/LV stations are more than 25 years old. From the mentioned groups only the HV and MV cable lines and overhead lines are less than 25 years old (Fig. 8) (Tomczykowski 2015). It is, however, worth mentioning that the highest voltage lines are in better condition, only $10 \%$ of $400 \mathrm{kV}$ overhead lines are over 35 years old.

It is easy to notice that the technical condition of the distribution networks is diverse. As a result, there are difficulties in maintaining electricity parameters in rural areas, where long runs of low voltage networks often occur. Network energy losses amounting to an average $8.2 \%$ are also a problem, and in the case of the above-mentioned overhead lines, up to $12 \%$, while the EU-15 average is $5.7 \%$. This situation has a negative impact on the energy security of the country, particularly in rural areas, thus hampering their development.

Pomerania, Warmia, Masuria and the eastern part of the country are regions that require significant investments in the energy infrastructure. However, the greatest threat of an energy failures 


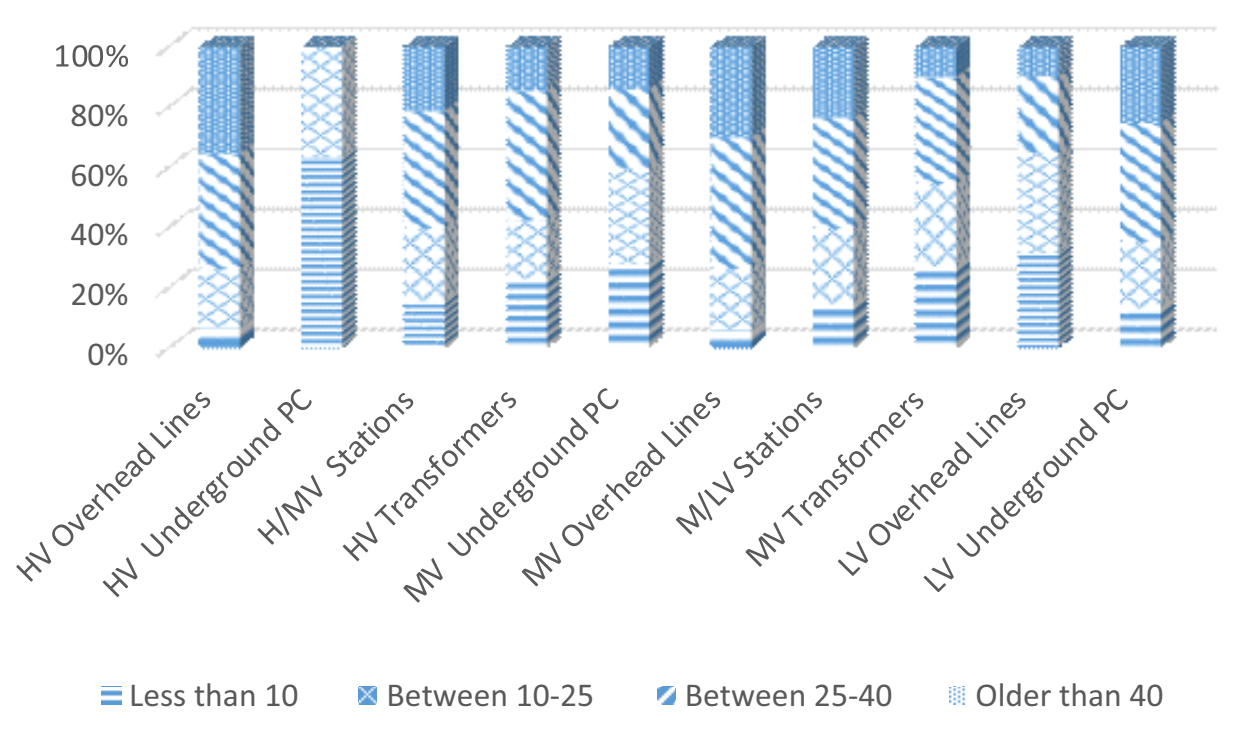

Fig. 8. Age structure of selected elements of the distribution network in Poland (Tomczykowski 2015)

Rys. 8. Struktura wiekowa wybranych elementów sieci dystrybucyjnej w Polsce

is projected in the areas closest to the north of Łódź. The reason for this is the small number of power generation sources and the low density of the power grids, combined with a high demand for energy. The operators have declared the construction of new sources with a capacity of 10.5 GW (PLN 54 billions) between 2014-2018 and the modernization of the existing sources, which requires about PLN 12 billion (Report... 2015). Table 3 presents the future generation capacities of conventional units that are currently under construction (Report... 2015).

The probability of a large accident covering a huge area of the country is, fortunately, low. This can only takes place due to the occurrence of several unfavorable factors, such as high electricity consumption and bad weather conditions.

TABLE 3. New generation capacities in Poland

TABela 3. Nowe moce wytwórcze w Polsce

\begin{tabular}{|l|c|c|c|}
\hline \multicolumn{1}{|c|}{ Investor } & Location & Power [MW] & Planned or implemented completion time \\
\hline ENEA & Kozienice & 1075 & completed in 07.2017 \\
\hline PKN ORLEN SA & Płock & 596 & completed in 12.2017 \\
\hline PGE & Opole (block 5) & 900 & 08.2018 \\
\hline TAURON & Jaworzno & 910 & 03.2019 \\
\hline PGE & Opole (block 6) & 900 & 04.2019 \\
\hline PGE & Turów & 496 & 08.2019 \\
\hline
\end{tabular}

Source: Report... 2015. 
However, such situations are observed in Poland. An example of weather impacts may be the largest blackout in Poland, which occurred in Szczecin in 2008. Weather anomalies occurred in Szczecin and a large part of the Westpomeranian province on July 4, 2008 in the afternoon and at night from April 7 to 8 . There was a strong wind, a lot of wet snow, and the temperature ranged from $-1^{\circ} \mathrm{C}$ to $+4^{\circ} \mathrm{C}$. Five electricity sources were installed in the area covered by the failure, in the technology based on hard coal: Dolna Odra Power Plant, Pomorzany Power Plant, Szczecin Power Station and two Heat and Power Plants Z. Ch. 'Police' SA, two larger wind farms in Zagórz and Jagniątków near Wolin and several dozen small hydro and wind farms. The mentioned sources of production were connected to the national power system on MV and HV voltages: 110,220 and $400 \mathrm{kV}$. PSE was responsible for the transmission of electricity in this area, and Enea Operator and Energa Operator for the distribution.

The failure caused a complete lack of power supply in two areas: the left-bank part of Szczecin and in Goleniów and its vicinity. In addition, damage to medium and low voltage networks caused a lack of power in many other towns.

Fortunately, the range of the failure was local and did not adversely affect the operation of the national power system. The $400 \mathrm{kV}$ Krajnik-Dunowo transmission line running through the affected area was not damaged. The Dolna Odra system power plant worked without interruption. Electricity security in the entire country was not threatened (Report... 2008).

An example is also the effects of the storm between August 10-12, 2017, having tragic consequences, which completely destroyed numerous elements of the critical power infrastructure, including the Bory Tucholskie region, thus depriving thousands of consumers of access to electricity. The Enea Operator announced that on August 27, 2017, the electricity supply was restored throughout the entire area managed by the Operator. In many places power grids had to be rebuilt practically from scratch, which, with such a scale of destruction, showed the efficiency and capabilities of the repair teams (Report URE... 2017; Energetyka24 2018).

Another example are energy shortages in summer and winter, when due to the water deficit caused by high and low temperatures respectively, it is impossible to effectively cool energy blocks from the so-called open cooling blocks. This results in the need to limit or even stop their work (PKEE... 2016).

It should be emphasized that the situation is also complicated by the increased demand for energy during periods of extreme temperatures. Increased collection needs combined with the inability to generate the desired amounts of energy pose a serious threat to the stability of the country's energy system. The situation from 2015 is worth recalling here, when in August a shortage of generation capacity occurred in The National Power System (Fig. 9), and it is a warning that such situations may be repeated (PKEE... 2016).

In the Report of the Supreme Audit Office, it was even stated that "the value of social losses caused by the lack of sufficient energy supplies in 2020-2030 may amount, according to expert estimates, to PLN 70 billion" (Report... 2015). Unfortunately, despite the urgent need for the obsolete replacement and construction of new infrastructure, financial shortages mean that the directions of its modernization are limited in a large number of cases to conservative works in the scope of ongoing repairs resulting from operational wear and the impact of atmospheric factors. 


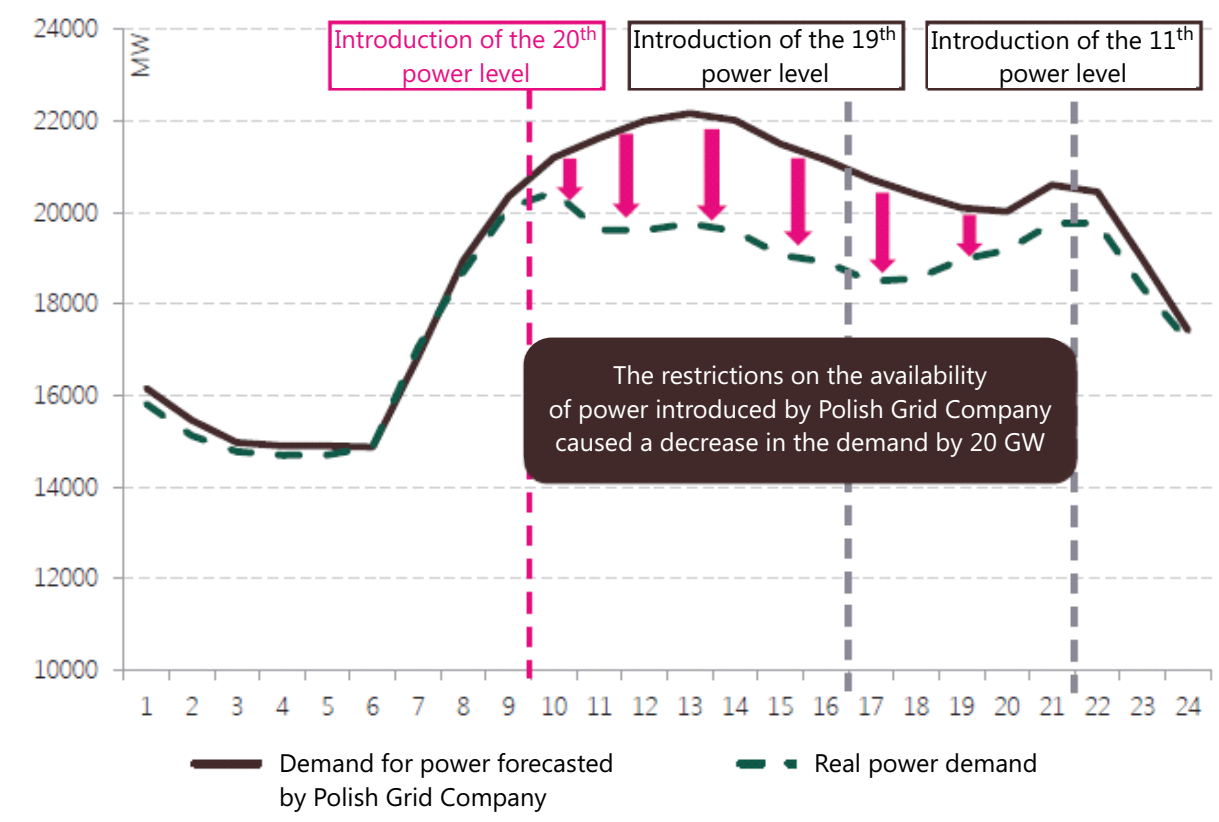

Fig. 9. The situation occurred in the national energy system on August 10, 2015 (PKEE... 2016)

Rys. 9. Sytuacja zaistniała w krajowym systemie energetycznym 10 sierpnia $2015 \mathrm{r}$.

\section{Limitations in the supply of electricity}

Restrictions in the electricity supply in 2017 were caused by failures of the distribution network, caused mainly by unfavorable weather conditions. Most often, they took place in October: 18,592 failures (including 18,576 caused by bad weather conditions) and December: 4,177 (including 4,055 caused by bad weather conditions). The least number of failures occurred in May: 83 and September: 288. Every month interruptions in the power supply were mainly caused by bad weather conditions. During the whole year there were 48,849 cases of energy supply reduction, of which 47,417 resulted from bad weather conditions and 1,432 here caused by other reasons. In 2016 were 10,732 cases of energy supply reduction, of which 9,561 resulted from bad weather conditions and 1,171 were caused by other reasons (List... 2017). Thus, there is still space to identify the causes of more than a thousand failures.

It is also worth emphasizing that Poland's electrical critical infrastructure may also be sensitive to violent phenomena occurring in our geosphere (Popielawska 2002; Stanisławska and Ernst 2007). The fact given by the Swedes (Kielen 2004), in the previous maximum of solar 
activity, during the so-called 'Halloween Storm', in October and November 2003 is particularly noteworthy. Disturbances were noted (at 07:46 am, October 29 and at 6:04 pm on November 20) in the supply of electricity from Poland to Sweden by the undersea line SwePol $400 \mathrm{kV}$ (Thorberg 2012).

\section{Actions to increase the liquidity and reliability of power infrastructure operation}

The key factor guaranteeing the increase in the efficiency of the power infrastructure in Poland is to ensure diversification of the method of obtaining electricity. The classic, coal-based or even nuclear energy methods will become ineffective in the wider time horizon. An example may be France, where most of the power plants need a large amount of water to cool reactors, which in the case of, for example, heat and related shortages, limits the possibility of their functioning (IAEA ... 2012).

An alternative is the use of renewable energy sources, although in this case also expert opinions are divided. In particular, the example of Poland indicates great administrative difficulties in the construction of, for example, wind farms. However, it should be noted that the diversification of supplies based on solar, wind, water and biogas plants is an alternative that guarantees a smooth and constant energy supply. Depending on the season, it is possible to regulate the amount of energy produced by the source that allows for optimal adaptation to the atmospheric conditions.

Another way to diversify is energy import. Acquiring energy from, for example, Germany, which in the summer has significant surpluses due to the fact that there are a considerable number of solar installations seems to be a good practice (Wirth 2018).

In addition to purely technical solutions, attention should be paid to increasing the production capacity and reducing energy consumption. The first mechanism consists in creating the so-called capacity market (called CRM - Capacity Reliability Mechanism), on which electricity generators would receive remuneration not only for energy actually sold, but also for the readiness of power units to produce it (Erbach 2017).

The second is based on the guarantee of energy consumption reduction (so-called negawatts) by entities that will receive an appropriate gratuity from PSE (TOE Report... 2016). 


\section{Technologies for maintaining the continuity of the electricity supply}

The specificity of the temporary electricity supply is related to the ERS (Emergency Restoration Systems), used since the 1970s. They were first used by American and Canadian Lindsey and SBB, and in Europe by the Dutch company KEMA. They cover two groups of solutions related to temporary lines and mobile generators. Their main advantages include quick assembly, container storage, no foundation of segment plates (a special plate is used), no need to use heavy construction equipment for their assembly, simple hanging and connecting wires and the possibility of multiple use (Pilch 2010).

The use of temporary techniques for maintaining the power supply in Poland requires the introduction of appropriate legal regulations. It seems that the most effective suppression of these regulations should be legal acts related to crisis management, and especially the protection of critical infrastructure.

In practice, ERS techniques can be used both in post-failure conditions and in the event of a significant decline in the performance of fixed-line networks. In order to use them effectively, however, it will be necessary to properly prepare companies dealing in the construction or reconstruction of energy infrastructure, in particular critical infrastructure. Moreover, it is necessary to continue adjusting the nature of ERS elements to threats to the functioning of the power infrastructure existing in Poland.

\section{Summary}

Maintaining the stability and efficiency of the power system functioning in Poland is one of the key factors in ensuring the energy security of our country. Its considerable sensitivity and susceptibility to damage results mainly from the advanced age of a significant number of installations used for generating and transferring electricity. Also, the lack of diversification of supplies, considered both in the dimension of the supplying entity's differentiation, as well as the method of energy production, exposes the power system to the risk of serious energy shortages, especially at the time of extreme temperatures.

In addition, the Polish energy sector is caught up in a number of connections and dependencies resulting from international commitments. It is determined by tightened climate regulations, restrictions in energy resources, mechanisms supporting the development of renewable energy, large fluctuations in fuel prices, and even the determination of electricity demand. It is therefore necessary to determine the strategic deposits of energy resources and to prevent the creation of infrastructure in their area. This is primarily about lignite deposits and gas from unconventional 
resources, the use of which gives a chance to change the national energy structure. In addition, maximizing the country's independence from the supply of energy resources from one region should be taken into account. It is also important in this aspect to reduce the energy intensity of our economy through the modernization of energy and heating. Modifications require production units, transmission and distribution networks, as well as works related to the use of nuclear and renewable energy, the sources of which are currently too scattered. This development must be accompanied by a significant reduction in the emission of dust and pollution into the atmosphere, in particular nitrogen compounds, sulfur dioxide, carbon monoxide, PM10 and PM2.5, benzo(a) pyrene or polycyclic aromatic hydrocarbons. Achieving these objectives will be possible thanks to the modernization of the energy and heating sector, the increase of energy efficiency and the replacement of traditional boilers with alternative energy sources.

It has to be emphasized that Poland's electrical critical infrastructure may also be sensitive to violent phenomena occurring in the Earth's magnetosphere.

The magnitude of the above-mentioned issues shows that interdisciplinary research dedicated to diagnosing factors that could, to any extent, threaten the security of Polish power critical infrastructure, can positively influence the increase level of security.

The work was done as part of a project financed by the National Science Center, DEC-2016/22/E/HS5/00406.

\section{References}

BIELECKI, S. 2017. Energy magazines and virtual power plants - solutions to the problems of unstable generation of electricity (Magazyny energii $i$ wirtualne elektrownie - rozwiąania na problemy niestabilnej generacji energii elektrycznej). Energetyka Wodna 2 (22), pp. 18-23 (in Polish).

Biuletyn... 2017. Biuletynu Urzędu Regulacji Energetyki nr 4/2016 - 1/2017, pp. 60-62.

Charles... 2018. Charles River Associates, 2018. CRA Insights: Energy, The impact of US LNG on European gas prices.

DoŁowy et al. 2015 - DoŁOwY, K., KRASZEWSKI, A. and RÓŻYCKI, S. 2015. Power lines of the highest voltages. Information for public administration and society (Linie elektroenergetyczne najwyższych napięć. Informator dla administracji publicznej i społeczeństwa). PSE S.A., Konstancin-Jeziorna, p. 20 (in Polish).

Enea 2018. Enea S.A. [Online] www.firma.enea.pl [Accessed: 2019-01-06] (in Polish).

Energa 2018. Grupa Kapitałowa Energa. [Online] www.energa.pl [Accessed: 2019-01-06] (in Polish).

Energetyka polska 2018. [Online] www.energetyka-polska.pl [Accessed: 2019-01-06] (in Polish).

Energetyka24 2018. [Online] www.energetyka24.com [Accessed: 2019-01-06] (in Polish).

ERBACH, G. 2017. European Parliamentary Research Service, Members' Research Service, PE 603.949.

EU... 2016. EU Reference Scenario 2016 Energy, transport and GHG emissions trends to 2050, Luxembourg: Publications Office of the European Union, 2016, p. 42.

European Council... 2014. European Council 23 and 24 October 2014 - Conclusions, EUCO 169/14, p. 6. GK PGE, 2018. Grupa Kapitałowa Polska Grupa Energetyczna. [Online] www.gkpge.pl [Accessed: 201901-06] (in Polish).

GUS... 2018. Central Statistical Office. Renewable energy in 2017 (Główny Urząd Statystyczny. Energia ze źródeł odnawialnych w 2017 r.), Warszawa 2018, p. 24 (in Polish). 
HoltgRewe, U. 2015. Services Research Along The Service Process: An overview study to support UNI Europa's services policy project, Vienna, p. 7.

IAEA... 2012. International Atomic Energy Agency, Efficient Water Management in Water Cooled Reactors, IAEA Nuclear Energy Series Technical Reports, No. NP-T-2.6, Vienna, 2012.

KIELEN, B. 2004. Solstormar, transienta geomagnetiska störningar, Elforsk report 03:33. Stockholm, Sweden: Elforsk AB.

LitPol, 2018. [Online] www.litpol-link.com/pl [Accessed: 2019-01-06] (in Polish).

National... 2013. National Critical Infrastructure Protection Program. Annex 1: Characteristics of critical infrastructure systems (Narodowy Program Ochrony Infrastruktury Krytycznej. Załacznik 1: Charakterystyka systemów infrastruktury krytycznej), 2013, pp. 4, 6, 11 (in Polish).

PASKA, J. and SURMA, T. 2017. Winter package of the European Commission and directions and implementation of policies and energy until 2030 (Pakiet zimowy Komisji Europejskiej a kierunki i realizacja polityk i energetycznej do 2030 roku). [In:] Połecki Z., Pijarski P., red., 2017 - Rynek energii elektrycznej, Lublin, pp. 7-17 (in Polish).

PILCH, W. 2010. Maintenance of electricity supply continuity with temporary solutions (Utrzymanie ciagtości zasilania energia elektryczna odbiorców za pomoca rozwiązá tymczasowych). Elektroenergetyka no 2, p. 74 (in Polish).

PKEE... 2016. PKEE Polish Electricity Association (Polski Komitet Energii Elektrycznej), 2016. Power market, or how to avoid a blackout. Analysis of the legitimacy of implementing a comprehensive power market mechanism in Poland (Rynek mocy czyli jak uniknać blackoutu. Analiza zasadności wdrożenia kompleksowego mechanizmu rynku mocy w Polsce), pp. 10, 33 (in Polish).

Polish... 2016. Polish power sector getting the facts straight (Niepopularne fakty o polskiej energetyce), PKEE 2016, p. 9 (in Polish).

POPIELAWSKA, B. 2002. Space weather is a very mundane matter (Pogoda kosmiczna bardzo przyziemna sprawa). Wybrane Problemy Geofizyki Wspótczesnej M-25 347, pp. 305-319 (in Polish).

PSE, 2018. Polskie Sieci Elektroenergetyczne S.A. [Online] www.pse.pl [Accessed: 2019-01-06] (in Polish).

Quarterly... 2017. Quarterly Report on European Electricity Markets. Market Observatory for Energy. DG Energy Vol. 10, 1 kwartał 2017, p. 6.

Report TOE... 2018. Report of the Energy Trading Society. Electricity and Gas Market in Poland (Raport Towarzystwa Obrotu Energia. Rynek Energii Elektrycznej i Gazu w Polsce). Stan na 31 marca 2018 r., Warszawa 2018, pp. 17-19 (in Polish).

Report... 2008. Report of the Team for the Investigation of Causes and Effects of the Energy Disaster set up by the West Pomeranian Voivode No. 154/2008 dated 22 April 2008 (Raport Zespolu ds. Zbadania Przyczyn i Skutków Katastrofy Energetycznej powołanego zarządzeniem Wojewody Zachodniopomorskiego $n$ r 154/2008 z dnia 22 kwietnia 2008 roku) (in Polish).

Report... 2015. Report of the Supreme Audit Office Information on the results of the audit. Providing Generating Power in Conventional Electricity (Raport Najwyższej Izby Kontroli Informacja o wynikach kontroli. Zapewnienie Mocy Wytwórczych w Elektroenergetyce Konwencjonalnej), Warszawa 2015, pp. 76, 31, 10, 8 (in Polish).

REE, 2018: Electricity market (Rynek energii elektrycznej) [Online] www.rynek-energii-elektrycznej.cire. pl [Accessed: 2019-01-06] (in Polish).

Report... 2016. Report by the Polish Electricity Association. Capacity Market as means to avoid blackouts. Assessment of the impact of implementation of a comprehensive capacity market mechanism in Poland, 2016, p. 12.

Report URE... 2017. Report on the Activities of the President of the Energy Regulatory Office in 2017 (Sprawozdanie z Działalności Prezesa Urzędu Regulacji Energetyki w 2017 r.), Warszawa 2018, pp. 123-124, 127 (in Polish). 
Report... 2012. Report of the Minister of Economy on the results of monitoring the security of gas fuel supplies for the period from January 1, 2012 to December 31, 2012 (Sprawozdanie Ministra Gospodarki $z$ wyników monitorowania bezpieczeństwa dostaw paliw gazowych za okres od dnia 1 stycznia $2012 \mathrm{r}$. do dnia 31 grudnia 2012 r.) (in Polish).

Report... 2015. Report of the Minister of Economy on the results of monitoring the security of electricity supply for the period from January 1, 2013 to December 31, 2014 (Sprawozdanie Ministra Gospodarki z wyników monitorowania bezpieczeństwa dostaw energii elektrycznej za okres od dnia 1 stycznia 2013 r. do dnia 31 grudnia 2014 r.), Warszawa 2015, p. 63 (in Polish).

Report... 2017. Report of the Minister of Energy on the results of monitoring the security of electricity supply for the period from January 1, 2015 to December 31, 2016 (Sprawozdanie Ministra Energii z wyników monitorowania bezpieczeństwa dostaw energii elektrycznej za okres od dnia 1 stycznia 2015 r. do dnia 31 grudnia 2016 r.), Warszawa 2017, p. 12 (in Polish).

STANISŁAWSKA, I. and ERNST, T. 2007. Space weather in everyday life. Civilization and elements (Pogoda kosmiczna w życiu codziennym. Cywilizacja i żywioły), Monografie Instytutu Meteorologii i Gospodarki Wodnej, p. 213-222 (in Polish).

Strategy... 2014. Strategy for Energy Security and Environment perspective until 2020 (Strategia Bezpieczeństwo Energetyczne i Środowisko perspektywa do 2020 r.), Warszawa 2014, p. 11.

Tauron 2018. TAURON Polska Energia S.A. [Online] www.tauron-pe.pl [Accessed: 2019-01-06] (in Polish).

THORBERG, R. 2012. Risk analysis of geomagnetically induced currents in power systems. Lund, s. 52.

TOE Report... 2016. TOE Report. Electricity and gas market in Poland. Status on 31 March 2016.

TOMCZYKOWSKI, J. 2015. Power networks of the five largest operators (Sieci energetyczne pięciu największych operatorów). Energia elektryczna nr 5, pp. 23-25 (in Polish).

WIRTH, H. 2018. Recent Facts about Photovoltaics in Germany, Fraunhofer ISE.

Zestawienie... 2017. List of quantitative data regarding the functioning of the National Power System in 2017 (Zestawienie danych ilościowych dotyczacych funkcjonowania Krajowego Systemu Elektroenergetycznego w 2017 roku) (in Polish). 


\title{
Infrastruktura elektroenergetyczna w Polsce i jej wrażliwość na awarie jako element systemu bezpieczeństwa energetycznego
}

\author{
Streszczenie
}

Bezpieczeństwo energetyczne w Polsce to w chwili obecnej jeden z kluczowych elementów wpływających na system bezpieczeństwa narodowego. Utrzymanie w sprawności eksploatacyjnej oraz permanentna modernizacja, zarówno elektrowni, jak i stacji transformatorowych oraz sieci przesyłowych, stanowi punkt wyjścia do zapewnienia bezpieczeństwa elektroenergetycznego w naszym kraju. Jest to istotne wyzwanie, zważywszy na wiek elementów energetycznej infrastruktury krytycznej w Polsce, a także permanentny wzrost zapotrzebowania na energię elektryczną. Implikuje to systematyczny wzrost rangi bezpieczeństwa energetycznego kraju. Wskazane w niniejszym opracowaniu liczne zdarzenia i anomalie, które towarzyszą nam w życiu codziennym, jak chociażby nawałnice, które przeszły nad Polską w nocy z 11 na 12 sierpnia 2017 r. dowodzą znacznej wrażliwości energetycznej infrastruktury krytycznej na wpływ różnego rodzaju negatywnych czynników. Szczególnie zagrożone jest bezpieczeństwo polskiej infrastruktury krytycznej, związanej z dystrybucją energii elektrycznej. Pożądane są zatem nie tylko bieżące naprawy i modernizacje elementów systemu elektroenergetycznego, lecz również prace związane z dostosowaniem infrastruktury do obecnych, a nawet prognozowanych zapotrzebowań, wyzwań i zagrożeń. W obliczu zaprezentowanych wyników badań przebudowa polskiego systemu elektroenergetycznego, a także wdrożenie innowacyjnych rozwiązań produkcji, przesyłu i dystrybucji energii wydają się być nieuniknione. Wskazane są zatem interdyscyplinarne badania i analizy, pozwalające na zwiększenie poziomu bezpieczeństwa energetycznej infrastruktury krytycznej, poprzez jak najlepsze zdiagnozowanie czynników mogących nawet w niewielkim stopniu zagrażać temu bezpieczeństwu.

SŁowA KLUCZOWE: energetyka w Polsce, infrastruktura energetyczna, awarie systemu energetycznego, bezpieczeństwo energetyczne 